\title{
Communication and Occupational Health Training Programs for Traditional Market Traders in Karanganyar
}

\author{
Haris Setyawan \\ Occupational Health and Safety Department \\ Faculty of Medicine, Universitas Sebelas Maret \\ Surakarta, Indonesia \\ Isna Qodrijati \\ Occupational Health and Safety Department \\ Faculty of Medicine, Universitas Sebelas Maret \\ Surakarta, Indonesia
}

\author{
Tutug Bolet Atmojo \\ Occupational Health and Safety Department \\ Faculty of Medicine, Universitas Sebelas Maret \\ Surakarta, Indonesia
}

\author{
Seviana Rinawati \\ Occupational Health and Safety Department \\ Faculty of Medicine, Universitas Sebelas Maret \\ Surakarta, Indonesia
}

\begin{abstract}
Karanganyar is one of the developing districts in central Java, in both the economic and health sectors. One of the economic and health developments that deserve special attention in Karanganyar is the number of traditional markets that have not implemented the concept of health and good sanitation. Unhealthy traditional markets have the potential to become a hotbed of infectious diseases that are harmful to the health of surrounding communities. Trade ministry data of 2017 mentions the number of markets in Indonesia at around 13,450 traditional markets with 12.625 billion traders. The results of preliminary observations indicate Malangjiwan Colomadu market included in the category of unhealthy market characterized by the number of puddles, slippery roads and animal carriers of diseases such as rats, cockroaches, mosquitoes and flies roaming around the market. Communication and occupational health training programs for traditional market traders are very important activities to teach market traders to prevent various diseases in traditional markets. Participants in this program include 23 market traders working in Pasar Malangjiwan Karanganyar area. The program is carried out using extension, communication and training methods by providing information and simulations of 3 topics covering clean and healthy living behaviours, waste sorting practices and 6-step handwashing practices. An assessment is done by giving a questionnaire in 2 stages of the pre-test and post-test stage. The results of this program have increased knowledge and practice on clean and healthy living behaviour (24.4\%), six step hand-washing simulation $(21.8 \%)$ and sorting waste practices $(\mathbf{1 5 . 6 \% )}$.
\end{abstract}

Keywords_clean and healthy living behaviour; communication programs; health training; traditional market traders

\section{INTRODUCTION}

Health is a human right and also a human resource investment; it greatly contributes to improving the Human Development Index, which includes 3 indicators, namely education level, health degree and economic ability of the community [1]. Maintenance of public health will spur work productivity; it becomes a must for the community to maintain, improve and protect health in work [2]. Karanganyar is one of the developing districts in central Java, in both the economic and health sectors [3]. One of the economic developments and decent health of special attention in Karanganyar is the number of traditional markets that have not applied the concept of health and good sanitation. Trade ministry data of 2017 mentions the number of markets in Indonesia at around 13,450 traditional markets with 12.625 billion traders [4]. Unhealthy traditional markets have the potential to become a hotbed or source of infectious diseases that are harmful to health [5] Based on the observation result, the Malangjiwan Colomadu market is included in the category of unhealthy markets with a value of 7,089 ; the survey result from 50 kiosks of merchants obtained 20\% healthy, 62\% less healthy and $18 \%$ unhealthy.

In the Malangjiwan Colomadu market environment, there are still garbage piles, water puddles, slippery and uneven roads as well as animal disease vectors such as rats, cockroaches and mosquitoes. Traditional market traders are still less concerned with healthy clean living behaviour in preventing various disease transmissions. Based on the above, it is necessary to improve healthy hygiene behaviour in the Malangjiwan market; one of the efforts to do this is to implement a communication program and health counselling on traditional traders in Karanganyar so that various diseases can be prevented. This would increase the health degree to traders of the traditional market, especially the traditional traders in Pasar Malangjiwan Karanganyar. The program is implemented through 4 activities: Clean and Healthy living behaviour, sorting waste practice, six step hand-washing simulation and the establishment of a work health post. 


\section{MethodS}

A Communication and occupational health training program on traditional market traders in Karanganyar is dedicated to the community, conducted by D4 Occupational Health and Safety Program in collaboration with Puskesmas Colomadu and Pakwanwan Market Management, implemented through training and simulation program. This program was implemented in December 2017 in the Subdistrict Hall of Colomadu. This activity was attended by traditional market traders, amounting to 23 traders involving speakers from Head of Puskesmas Colomadu and a Lecturer from D4 Occupational Health and Safety. The instrument used to see the success of the communication and training program is a questionnaire. The assessment questionnaire covers 3 topics: Clean and Healthy Lifestyle, waste separation practices and 6-step handwashing practices. To see the success of this program, the questionnaire was given in 2 stages, namely the pre-test and post-test stage.

\section{RESULTS AND DisCUSSION}

The Malangjiwan Market is located in Malangjiwan Village, Colomadu District, Karanganyar Regency with an area of 4,951 sq. m. The northern border is adjacent to Ngemplak Subdistrict, the west is adjacent to Bolon Village, Regency of Kartasura in the south and Paulan in the east. Traders in the Malangjiwan market consist of various types of businesses with the 425 traders. The type of business markets include: Raw food material and food that is easily rotten, raw food material and dried food, cooked or fast food, photocopy and tailor.

TABLE I. THE PRE AND POST-TEST TRAINING SCORE IN OCCUPATIONAL HEALTH PROGRAMS

\begin{tabular}{|c|c|c|c|c|c|}
\hline \multirow[t]{2}{*}{ No } & \multirow[t]{2}{*}{ Questionnaire } & \multicolumn{2}{|c|}{$\begin{array}{l}\text { The Average of } \\
\text { Training Score } \\
(\%)\end{array}$} & \multirow{2}{*}{$\begin{array}{c}\text { The Increase } \\
\text { in Knowledge } \\
\text { and Practices } \\
(\%)\end{array}$} & \multirow[t]{2}{*}{$\mathbf{N}$} \\
\hline & & Pre & Post & & \\
\hline 1 & $\begin{array}{lr}\text { Clean } & \text { and } \\
\text { Healthy Living } \\
\text { Behaviour }\end{array}$ & $56,4 \%$ & $80,8 \%$ & $24,4 \%$ & 25 \\
\hline 2 & $\begin{array}{l}\text { Six Step Hand- } \\
\text { Washing } \\
\text { Simulation }\end{array}$ & $68,2 \%$ & $90 \%$ & $21,8 \%$ & 25 \\
\hline 3 & $\begin{array}{l}\text { Sorting } \quad \text { Waste } \\
\text { Practices }\end{array}$ & $64,4 \%$ & $80 \%$ & $15,6 \%$ & 25 \\
\hline
\end{tabular}

\section{A. Clean and Healthy Living Behaviour}

'Clean and healthy life' represents a set of behaviours that are practiced on the basis of awareness as a result of learning. This enables an individual or group to help themselves in the field of health and play an active role in realizing the degree of public health [6]. The benefits and objectives of the behaviour of clean and healthy living is to increase the knowledge, awareness, the willingness of the community to live healthy, as well as increase the active role of the community including the private and business world, in an effort to obtain an optimal degree of life [7]. The problem in health behaviour in the business world, especially the market traders, is the low knowledge and awareness about various diseases that can occur due to inappropriate disposal, poor sanitation of sewage disposal, lack of garbage availability and unhygienic market traders who use their hands to pick up and wrap food that they sell to the buyer. Training of clean and healthy life behaviour aims to educate traders about traditional markets so that clean, healthy living practices can be improved, especially in the activities of buying and selling traditional markets. In table 1, an increase can be seen in knowledge and practice of clean and healthy life behaviour by $24.4 \%$. The increase occurs because of training to improve knowledge and awareness of clean healthy life behaviour, which includes 5 basic materials such as definition, benefits, goals, concepts and behaviour of clean healthy life. Based on research conducted by Susanto, there are significant differences $(p<0.05)$ between respondents who were given knowledge about the behaviour of clean and healthy life versus respondents who were not given knowledge [8]. In addition to knowledge, the motivation and belief factor can encourage or inhibit changes in one's clean life behaviour [9]

\section{B. Six Step Hand-Washing Simulation}

Environmental conditions in less hygienic and healthy traditional markets increase the risk of traders catching various diseases. Hands become a medium of transmission of various diseases that can enter the body either from bacteria, viruses or parasites [10]. One of the proper measures to prevent the transmission of the disease is by washing hands properly [11]. Unfortunately, although it is cheap and easy, hand washing is not yet a culture done by people in Indonesia, especially in traditional markets. This handwashing 6-step simulation program aims to educate traditional market traders, especially in Malangjiwan Karanganyar Market to be more concerned about disease prevention through proper handwashing program. In table 1, it can be seen that there is an increase in knowledge and practice by $21.8 \%$. Increased knowledge and practice can occur because of intervention through health education, especially the simulation of 6 steps of hand washing. According to Mubarak, the purpose of health education is to help people identify problems according to their own needs, be able to understand their own problems and decide the right activities to improve the degree of health [12].

\section{Sorting Waste Practices}

Solid waste is part of something that is not used, disliked or something to be thrown away, which generally comes from human activities [13] Waste Management in Traditional Markets needs to be given more attention, considering many are seen as a place to pile up waste, which can lead to numerous vectors of diseases at that site [14]. The problems that often occur in Traditional Markets are the lack of regulation related to environmental health, the implementation of environmental impact analysis, environmental management and monitoring and environmental health activity in Traditional Markets not yet being a priority [15] [16]. Knowledge of solid waste or waste management must be 
owned by traditional market traders as a direct responsibility to the environment and the communities surrounding the market. The success of Traditional Market waste management can be seen by the level of knowledge and can also be determined from the attitude. Attitudes will affect the behaviour of traders to behave properly in carrying out waste handling and disposal efforts [17]. This knowledge and attitude support will directly affect real behaviour in managing waste [18]. To improve the knowledge, attitude and behaviour of managing waste in the market, there is a waste sorting practice program where market traders are used to dispose of waste in place, preventing the spread of various diseases in the market and facilitating the process of waste recycling. Based on table 1, it can be seen that the practice of the waste separation program has increased knowledge and practice by $15.6 \%$. Increased knowledge and practice has the smallest value of 2 other programs that have been implemented, i.e. healthy clean living behaviour and simulation 6 step hand washing. This can happen because the increase in knowledge and health practices must be in line with the availability of infrastructure facilities [19], especially the availability of adequate garbage, both in terms of number and type of trash. In terms of amount, the Malangjiwan Market consists of only some available garbage bins and cannot accommodate all the garbage from 425 traders. However, the market is yet to be equipped with organic and inorganic types of garbage bins.

\section{CONCLUSIONS AND SugGestions}

The program of communication and health training to the Traditional Market Traders in Karanganyar is one of the programs of dedication to the community, conducted by D4 Occupational Health and Safety Study Program in collaboration with Puskesmas Colomadu and Malangjiwan Market management, implemented through the training and simulation program. The results of this program have increased knowledge and practice on clean and healthy life (24.4\%), hand-washing hand simulation (21.8\%) and waste sorting practice $(15.6 \%)$. This health communication and training program will continue to be developed and implemented continuously through the Occupational Health Post program, whose members consist of manager and trader of the Malangjiwan market, Puskesmas Colomadu I and D4 Occupational Health and Safety Study Program of Universitas Sebelas Maret, with the goal to achieve a healthy market community.

\section{REFERENCES}

[1] R. Heriawan, "Indeks Pembangunan Manusia [Human Development Index]. Badan Pusat Statistik, Jakarta, p. 3, 2009.

[2] T. Koopman, C., Pelletier, K. R., Murray, J. F., Sharda, C. E., Berger, M. L., Turpin, R. S., ... \& Bendel, "Stanford presenteeism scale: health status and employee productivity,” J. Occup. Environ. Med., vol. 44, no. 1, pp. 14-20, 2002.

[3] H. Setyawan, Q. C. Pratiwi, I. Sjarifah, T. B. Atmojo, and Khotijah, "Environmental heat stress enhances crystallization in urine," in IOP Confernce Series : Earth and Environmental Science, 2017, pp. 1-7.
[4] I. D. Supraptini, R. Nainggolan, Elsa-Elsi, "Food Quality in Traditional Market at Several City in Indonesia,” Kualitas Bahan Makanan, vol. 10, no. 4, pp. 208-218, 2011.

[5] N. N. Haq and S. Tarumun, "Strategi Pengelolaan Drainase Pasar Tradisional Palapa di Kota Pekanbaru [Drainage Management Strategy of Palapa Traditional Market in Pekanbaru City],” Din. Lingkung. Indones., vol. 2, no. 1, pp. 17-25, 2015.

[6] A. I. F. M. Diana, F. Susanti, "Pelaksanaan program perilaku hidup bersih dan sehat (PHBS) di SD Negeri 001 Tanjung Balai Karimun [Implementation of Clean and Healthy Living Behavior Program in State Elementary School 001 Tanjung Balai Karimun],” J. Kesehat. Masy., vol. 8, no. 1, pp. 46-51, 2014.

[7] A. Tucunan, "Hubungan antara Faktor Predisposing, Enabling dan Reinforcing dengan Perilaku Hidup Bersih dan Sehat Tatanan Rumah Tangga di Kecamatan Siau Tengah Kabupaten Sitaro Provinsi Sulawesi Utara [Relationship between Predisposing, Enabling, and Reinforcing Factors and Clean and Healthy Living Behavior of Household in Siau Tengah District, Sitaro Regency, North Sulawesi Province],” Kesmas, vol. 7, no. 1, 2018.

[8] T. Susanto, L. Sulistyorini, and E. Wuri, "School health promotion : A cross-sectional study on Clean and Healthy Living Program Behavior ( CHLB ) among Islamic Boarding Schools in Indonesia,” Int. J. Nurs. Sci., vol. 3, no. 3, pp. 291-298, 2016.

[9] B. Happell, R. Stanton, W. Hoey, and D. Scott, "Knowing is not doing : The relationship between health behaviour knowledge and actual health behaviours in people with serious mental illness,” Ment. Health Phys. Act., vol. 7, no. 3, pp. 198-204, 2014.

[10] D. Nur. Anisa, "Pengaruh pendidikan kesehatan terhadap perilaku cuci tangan pakai sabun pada anak usia sekolah di SD 2 Jambidan Banguntapan Bantul [Influence of health education towards washing hand with soap behavior on child student at Elementary School 2 Jambidan Banguntapan Bantul]," Sekolah Tinggi Ilmu Kesehatan 'Aisyiyah Yogyakarta, 2012.

[11] A. Hashi, A. Kumie, and J. Gasana, "Hand washing with soap and WASH educational intervention reduces under- fi ve childhood diarrhoea incidence in Jigjiga District, Eastern Ethiopia : A communitybased cluster randomized controlled trial,” Prev. Med. Reports, vol. 6, pp. 361-368, 2017.

[12] K. Mubarak, W. I., Chayatin, N., \& Rozikin, Promosi kesehatan sebuah pengantar proses belajar mengajar dalam pendidikan [Health promotion, an introduction of teaching and learning process in education]. Yogyakarta: Graha Ilmu, 2007.

[13] Lilis Sulistyorini, "Pengelolaan Sampah dengan cara menjadikannya kompos [Garbage management by making it into compost]," J. Kesehat. Lingkung., vol. 2, no. 1, pp. 77-84, 2005.

[14] E. R. W. Lu Aye, "Environmental and economic analyses of waste disposal options for traditional markets in Indonesia,” Waste Manag., vol. 26, no. 10, pp. 1180-1191, 2006.

[15] A. Matter, M. Ahsan, M. Marbach, and C. Zurbrügg, "Impacts of policy and market incentives for solid waste recycling in Dhaka , Bangladesh,” Waste Manag., vol. 39, pp. 321-328, 2015.

[16] S. Zheng, W. Liu, and Q. Zhi, "Cleaner waste management : a review based on the aspects of technology, market and policy," Energy Procedia, vol. 104, pp. 492-497, 2016.

[17] F. Daniel, E. Ioannidi, Y. Sun, V. W. Jape, W. R. Bawono, S. Zhang, and F. J. A. Perez-cueto, "Consumers with high education levels belonging to the millennial generation from Denmark, Greece , Indonesia and Taiwan di ff er in the level of knowledge on food waste," Int. J. Gastron. Food Sci., vol. 11, no. February 2017, pp. 49-54, 2018.

[18] M. Alimohammadi and M. Youse, "Dataset on the knowledge, attitude and practices of biomedical wastes management among Neyshabur hospital' s healthcare personnel,” Data Br., vol. 17, pp. 1015-1019, 2018.

[19] H. Setyawan, "Risk Factors of Carpal Tunnel Syndrome among FoodPacking Workers in Karanganyar,” Kesmas Natl. Public Heal. J., vol. 11, no. 3, pp. 123-126, 2017. 